\title{
Jessie Street and the New Political Biography
}

\section{Lenore Coltheart}

Most political biographies of women are about female heads of state, heads of government, and parliamentary representatives, but most women who have exercised power on political structures and processes have done so as non-government actors. An expanded definition of political biography brings in these unofficial figures who 'impacted on policy, politics or government'. We probably should consider, too, the reverse vectors, as the influence of the geopolitical is too frequently understated in writing lives, as if these could ever be immune from either national politics or international relations. So political biography has much to teach across the whole field of the biographer, from the famous to the family historian and the appearance, largely since 1990, of political biographies of 'unofficial' women is encouraging. Books on women suffragists paved the way for more recent work like those on Marietta Tree, Shirley Graham Du Bois, Grace Hutchins and Anna Rochester (Seebohm, 1997; Horne, 2000; Lee, 2000), for example, which bring a diverse range of women within the political penumbra. Such work suggests a shift in feminist history, as well as in the study of politics, towards more contextual explanation of flows of power between public and private lives.

The subject of my work is feminist internationalist Jessie Street. Street died in 1970 at the age of 80 . I had started work on a study of connections between the humanitarian work of the League of Nations and the human rights functions of the United Nations Economic \& Social Council. Specifically I was interested in Australian women and the influence of NGOs on this work. It was not long before I encountered Jessie Street and she took over my project. She had thirty years of experience within the international network of women's NGOs, from her first visit to the League in Geneva in 1930 until her last UN session in New York in the 1960s. And I met her through two excellent publications. The Australian Dictionary of Biography is an invaluable resource for political biographers, but I want also to mention Heather Radi's 200 Australian Women (1988). The splendid index in this book reveals connections not always obvious in other Australian politics resources. Tracing vectors of influence between people and through organisational networks is every bit as important in what might be called 'non-government' political biography, as when the subject was officially a political actor. Perhaps Jim Walter's term, 'organic intellectual', can be adapted and the non-official figures be considered organic political actors. 
A year after I realised the work I was doing was turning into biography, I had a request from Jessie Street's family to do a revision of her 1966 autobiography, Truth or Repose. Like many others - including the prospective publisher - I thought initially this was not really a useful exercise, and perhaps not even possible. But the challenge was there and, while convincing the publisher, I convinced myself. The work of 'ghost-revising' an autobiography was an unusual task with the pragmatic advantage of making me live a lot closer with Jessie Street and able to talk frequently with her elder daughter, who generously read draft chapters and provided invaluable support. There were good and bad spin-offs. Soaking myself in my subject's own words made me realise how much she had needed a research assistant and a good editor - and then I knew just how to approach the work - but it took much longer than I had allowed. The new book also drew attention to this remarkable woman rather too soon for my own work to squeeze into the arc of media attention. But, for me, the premature publicity drew out unexpected angles of current opinion on Jessie Street and her story. ABC TV did a New Dimensions segment they called 'Radicals and Reformers' in 2003 and the following year the ABC Dynasties team could not resist giving her a large chunk of their episode on the Street law dynasty, so far a male preserve dominated by three Chief Justices of the NSW Supreme Court. The book's publication in March 2004 brought requests for interviews and talks, including Gerard Henderson's irresistible invitation to speak at the Sydney Institute on 'that dreadful Stalinist Jessie Street'.

Through the diversion of the new edition of the autobiography I came closer to knowing why I wanted to write a biography. The 'how' of the biography is more straightforward. Unusually for an unofficial political figure, a woman working through women's organisations, Jessie Street left a pretty good archival trail. There are copious files of official and personal letters, some diaries, lots of private and formal photographs, and many transcripts of speeches and broadcasts and drafts of articles. There is also a newspaper trail, presenting several Jessie Streets - from 1947 a 'Red Jessie' emerges. This Jessie Street also appears in ministerial minutes and memos, the asides on government records that reveal much about attitudes, and this same 'Red Jessie' is presented in her very substantial ASIO files.

As well as the archival trail, there are diverse informal discoveries from family and colleagues, both material and oral evidence. Place is also important particularly Yulgilbar, the property on the upper Clarence River in northern New South Wales where Jessie Street grew up. Equally important are the international trails. A three month trip in 2004 took me to possibly half the places she regularly visited or that were significant to her work, like San Francisco for instance. From April to June 1945 the Australian delegation to the conference setting up the United Nations stayed in the Sir Francis Drake Hotel. Unhappily, hotels are very bad at keeping guest register records for sixty years, 
but it was a great discovery to find that the hotel's English theme lived on, including doormen in beefeater rig. In New York I prowled Manhattan's lower East Side to find locations like the former girls' home where Jessie Street had worked in 1915. Washington, the headquarters of the World Women's Party where Jessie Street worked with Alice Paul from the 1930s, has now become an invaluable archive and museum.

Only half awake and exhausted after a jet-lagged sleep on my first morning in San Francisco, I stood waiting in the June dawn for the cable car outside the hotel thinking the Australian delegation in 1945 had taken two days to reach San Francisco, travelling under wartime conditions that included flying only at night. Suddenly I realised Jessie Street had stood where I stood. Despite the obvious changes to the city, all of it - my exhaustion the night before, my excitement on waking, the chilly sunrise, the gorgeous June sky, called up a similar day sixty years before. It was a good start on a discovery of the effect place has, a pointer to how biographical research needs to cross over methodological boundaries.

It was catching that idea that also attuned me to taking a more materialist approach. It became a lot easier to imagine my subject in a room, with details of curtains and chairs, her clothes, her bag of files and newspapers. The train station in Budapest in 1938, Le Bourget airport in 1951, the material surrounds of her travelling took shape. The vital issue of money has already been raised - Jessie Street's bank accounts and the fact that it was her own money she paid out is significant in explaining her profile in international NGO networks. Everything about everyday life including eating, drinking, smoking — when, how, with whom - are details not to be overlooked. If I was asked to paint a portrait of the objects most familiar to Jessie Street's everyday life, I could just about do it - a telephone, a bunch of the day's newspapers and her glasses, her passport and an airline ticket, her cigarettes and lighter, her capacious handbag full of files, her cameo brooch, her tiny diary full of scribbled appointments, her address book arranged by country, and a gift for someone, wrapped and ready to send.

It is with such details that real world connections can be caught in life stories. This is particularly important for the political biographer whose subject held no public political position. Jessie Street's work was done mostly through non-government organisations and international networks of women. As in any political biography her work can only be explained in the context of contemporary national and international political events, but with the unofficial activist, the big-picture context tends to sever detailed connections within private lives.

Questions that require evidence both from political history and from personal history are key points for remaking the connections of lives lived in a political context. Jessie Street failed to be elected to parliament and was stripped of her 
government appointments, so how she built power bases before and after these events is a key question. This kind of question means drilling down for detail while keeping antenna tuned to the broadest issues - like why is a power base necessary to participate in politics when this is what democracy is meant to offer for all of us? Issues central to biographies of official figures have this double effect when the subject is an 'organic' political figure working less visibly through cultural, rather than government channels. Asking how power is lost and what happens after it is lost similarly connects public events and personal issues, as does the big calculation, assessing the achievements and failures of one's subject. Peter Sekuless subtitled his 1978 biography of Jessie Street $A$ Rewarding but Unrewarded Life, a title almost as inappropriate a motif for Jessie Street as the one she gave to her autobiography, Truth or Repose (1966). Maybe both matters would have been sorted had she used the title she first thought of: 'God I've had a lovely life'.

A life like Jessie Street's challenges the managerialist approach to political biography, counting goals met, agendas fulfilled and targets 'bullseyed' to rate the subject. Among the problems confronting the 'organic' political biographer is how to sum up and how to tie off so many threads of detail and big-picture banners. Perhaps the means is the end: the process of participating makes a political life. In this light, the non-government women activists whose work shaped the development of human rights in the twentieth century grew a form of international citizenship that can be conferred no other way but through its practice.

A life like Jessie Street's means following research paths that seem to lead in opposite directions, but perhaps this is the best way to attach political science, history, and international relations more firmly to life as we know it. 